\title{
METODE KRITIK SANAD DAN MATAN HADITS
}

Oleh : Zubaidah

Sekolah Tinggi Pendidikan Islam Bina Insan Yogyakarta

\section{Abstract}

Hadith is one of the sources of Islamic law, however, since the time of the Companions until now many hadith is weak and false circulating in the community, giving rise to an understanding that is not in accordance with Islamic law. Deals with the study of sanad and honor tradition, broadly covers two activities or stages that perform critical method sanad and perform critical method of selection of honor or honor hadith.

Hadits merupakan salah satu sumber hukum Islam, namun, sejak masa para sahabat hingga sekarang banyak hadits dhaif dan palsu yang beredar di masyarakat, sehingga menimbulkan pemahaman yang tidak sesuai dengan syariat Islam. Berkaitan dengan studi sanad dan matan hadis, secara garis besar meliputi dua kegiatan atau tahapan yaitu melakukan metode kritik sanad dan melakukan metode kritik matan atau seleksi matan hadits.

Kata kunci : kritik, hadits, sanad dan matan.

\section{A. Pendahuluan}

Pedoman hidup umat Islam sebagai sumber hukum adalah A-Quran dan Al-hadits yang sudah barang tentu tidak diragukan dan tidak dapat ditawar tawar lagi. Sebagai petunjuk hidup manusia Al-Quran masih bersifat umum. Oleh karena itu untuk mengapikasikan Al-Qur'an dalam kehidupan sehari-hari, sangat membutuhkan penjelasan-penjelasan berupa perkataan, 
perbuatan dan ketetapan dari Nabi Muhammad saw, yang disebut hadits.

Bahwa hadits merupakan salah satu sumber hukum Islam yang harus dipahami. Namun, sejak masa para sahabat hingga sekarang banyak hadits dhaif dan palsu yang beredar di masyarakat, sehingga menimbulkan pemahaman-pemahaman yang tidak sesuai dengan syariat Islam. Sebab itulah penting bagi setiap muslim memilah-milah hadits yang akan digunakan sebagai dasar hukum.

Mengingat begitu pentingnya hadits, maka studi atau kajian terhadap hadits akan terus dilakukan, bukan saja oleh umat Islam, tetapi oleh siapapun yang berkepentingan terhadapnya. Berbeda dengan ayat-ayat al-Qur'an yang semuanya dapat diterima, Sedangkan hadits tidak semuanya dapat dijadikan sebagai acuan atau hujjah. Hadits ada yang dapat dipakai ada yang tidak. Di sinilah letak perlunya meneliti hadits.

Agar dapat meneliti hadits secara baik diperlukan antara lain pengetahuan tentang kaidah dan atau metodenya. Dengan demikian, hadits berkedudukan sebagai sumber hukum kedua setelah Al-Qur'an. Adapun apabila dilihat dari sisi periwayatannya, AlQuran diturunkan secara mutawatir.

Sementara itu, untuk sanad dan matan atau teks hadis yang di dalamnya memuat informasi-informasi dari atau tentang Nabi Muhammad saw, secara 
metodologis masih jauh tertinggal. Karena itulah, hendaknya terus dilakukan upaya untuk mengembangkan atau merumuskan kaidah dan metode untuk studi kritik terhadap sanad dan matan hadis. Berkaitan dengan studi sanad dan matan hadis, secara garis besar meliputi dua kegiatan atau tahapan yaitu meakukan metode kritik sanad dan melakukan metode kritik matan atau seleksi matan hadtis.

Berangkat dari konsep tersebut, maka perlu pembahasan lebih rincil tentang studi kritik sanad dan matan hadits dari aspek metodenya. Hal ini penting karena dengan memahami kritik sanad dan matan hadits maka akan menambah pengetahuan tentang hadits sebagai salah satu sumber ajaran Islam.

\section{B. Metode Kritik Sanad}

1. Teori Kritik Sanad

Pengertian kritik sanad hadis berdasarkan pada terminologi kritik yang digunakan dalam ilmu hadis adalah kritik sanad adalah suatu penyeleksian yang ditekankan dan dimaksudkan pada aspek sanadnya. Sehingga menghasilkan istilah Sahih al-isnad dan Dha'if al-isnad ${ }^{1}$.Shihih al-isnad ialah seluruh jajaran perawi dalam suatu hadis berkualitas sahih, di samping juga adanya kebersambungan sanad, serta

1 Kamil, Sukron, Naqd Al-Hadis, terj. Metode Kritik Sanad dan Matan Hadis, Pusat Penelitian Islam Al-Huda, 2000. 
terbebas dari kerancuan (syadz) dan cacat('illat).Sedangkan Dha'if al-isnad adalah salah satu atau beberapa jajaran periwayatnya berkualitas dha'if atau bisa jadi karena tidak memenuhi kriteria kesahihan isinya. Dengan demikian, bukan berarti bahwa hadis yang telah diberi level sahih al-isnad itu layak disandingi sahih al-matan, atau sebaliknya hadis yang telah dinilai dha'if al-isnad juga berarti dha'ifal-matan.

Kaidah keshahihan sanad hadis yang ditetapkan ulama tidaklah seragam. Akan tetapi ada kaidahkaidah yang disepakati oleh ulama hadis dan masih terjadi sampai sekarang. Berdasarkan kaidah tersebut, sebuah sanad hadis barulah dinyatakan shahih apabila :

a. Sanad hadis bersambung (muttasit) dari awal sanad hingga ke Nabi (marfu).

b. Seluruh perawi hadis bersifat adil, yakni:

1) Beragama Islam,

2) Mukallaf,

3) Melaksanakan ketentuan agama Islam,

4) Menjaga maruah.

c. Seluruh perawi bersifat dabit, yakni: terpelihara hafalannya jika meriwayatkan hadis dari hafalannya, atau terpelihara catatannya jika ia meriwayatkan dari kitabnya), dan (2) mampu meriwayatkan hadis ada kesalahan. Perawi yang 
mempunyai sifat cadil dan dabit disebut sebagai tsiqah.

d. Sanad hadis terhindar dari syudzudz, yaitu tidak terdapat kontradiksi apapun dengan riwayat tsiqah atau riwayat yang lebih tsiqah darinya atau riwayat yang lebih banyak jumlahnya. Sanad hadis yang terhindar dari shadz disebut juga sanad mahfudz.

e. Sanad hadis terhindar dari illah, yakni: (1) tidak terjadi kesalahan penilaian tsiqah terhadap perawi yang sesungguhnya tidak tsiqah, dan (2) tidak terjadi kesalahan penetapan sanad yang tersambung. Illah baru dapat ditemukan dalam periwayatan tunggal seorang perawi (hadits gharib) dan adanya pertentangan dengan perawi lain yang lebih tinggi taraf kedabitan dan pengetahuannya. Illah secara umum terdapat dalam sanad, tetapi tidak jarang pula terjadi di dalam matan hadis.

Sementara itu, Ali Mustafa Ya'kub dalam bukunya yang berjudul Kritik Hadits menyatakan bahwa upaya untuk mendeteksi kedhabitan rawi dengan Membandingkan Hadis-hadis yang diriwayatkannya dengan Hadis lain atau dengan Al-Qur'an, dapat dilakukan melalui enam metode perbandingan Hadis, yaitu: 
1) Membandingkan hadis-hadis yang diriwayatkan oleh sejumlah Shahabat Nabi, antara yang satu dengan yang lain.

2) Membandingkan Hadis yang diriwayatkan oleh seorang rawi pada masa yang berlainan.

3) Membandingkan Hadis-hadis yang diriwayatkan oleh rawi-rawi yang berasal dari seorang guru Hadis.

4) Membandingkan suatu Hadis yang sedang diajarkan oleh seorang dengan Hadis semisal yang diajarkan oleh guru lain.

5) Membandingkan antara Hadis-hadis yang tertulis dalam buku dengan yang tertulis dalam buku lain, atau dengan hafalan Hadis.

6) Membandingkan Hadis dengan ayat-ayat AlQur'an².

Di samping dengan metode-metode perbandingan atau pencocokan Hadis, yang dalam istilah Ilmu Hadis disebut metode mu'aradhah atau muqaranah, untuk mendeteksi otentisitas Hadis para ulama juga menggunakan metode "Kritik Akal" (al-Naqd al-'Aqli). Menurut al-Mu'allimi, penggunaan akal untuk mengkritik otentisitas Hadis ini dilakukan melalui empat langkah, yaitu:

2 Ibid., hlm. 18 
1) Ketika rawi menerima Hadis

Para ahli hadis menetapkan bahwa Hadis dapat diterima apabila rawinya ketika menerima atau mendengar Hadis itu memilik sifat-sifat mumayyiz, dhabit, dan 'alim. Mumayyiz artinya ia dapat membedakan antara hal-hal yang benar dan salah, antara Hadis dengan yang bukan Hadis. Dhabit artinya ia memiliki kekuatan hafalan yang unggul, tidak pelupa, tidak sering keliru dan sebagainya. 'Alim artinya ia mengetahui arti dan maksud Hadis yang diterimanya.

2) Ketika rawi mengajarkan Hadis

Para ahli Hadis juga menetapkan bahwa tidak dibenarkan mengajarkan atau meriwayatkan Hadis-hadis dha'if apalagi Hadis-hadis palsu, kecuali dijelaskan kedha'ifannya.

3) Ketika menilai kredibilitas rawi

Para ahli Hadis dalam menetapkan bahwa seorang rawi dinyatakan tidak memiliki kredibilitas sebagai rawi Hadis, hanya berdasarkan keterangan satu orang saja. Artinya, dengan keterangan satu orang saja bahwa seorang rawi itu tidak 'adil, para ahli hadis sudah dapat menetapkan bahwa rawi seperti itu ditolak Hadisnya. 
4) Ketika menilai otentisitas Hadis.

Imam al-Syafi'i mengatakan bahwa kebanyakan hadis-hadis itu tidak dapat dibuktikan kebenaran atau tidaknya kecuali berdasarkan kebenaran atau tidaknya orang yang menyampaikan hadis-hadis itu. Hanya dalam beberapa hal saja ketentuan ini tidak berlaku.

Pernyataan Imam al-Syafi'i ini berarti bahwa kebanyakan Hadis tidak dapat dibuktikan otentisitasnya kecuali berdasarkan kebenaran sumber hadis dan para rawinya. Dan ini tidak lain adalah cara pendeteksian otentisitas hadis melalui akal semata. Sekiranya tidak mempergunakan akal untuk hal itu, tentulah setiap hadis akan diterima sebagai sesuatu yang bersumber dari Nabi SAW, tanpa mempertanyakan apakah para rawinya itu memiliki sifat tsiqah (kredibilitas) sebagai rawi atau tidak.

Demikian pula ketika para ahli hadis mempertanyakan apakah rawi tersebut memiliki sifat-sifat mumayyiz, dhabit, dan 'alim ketika ia menerima Hadis, apakah Hadis yang diajarkan itu Hadis dha'if atau palsu, apakah ia termasuk rawi majruh dan sebagainya; semuanya itu adalah penggunaan akal semata dalam mendeteksi otentisitas Hadis. Hal ini sekaligus menepis 
anggapan sementara orang bahwa para ahli Hadis tidak pernah menggunakan "kritik.

2. Langkah-Langkah Kegiatan Dalam Kritik Sanad Hadits

Syuhudi Isma'il dalam buku beliau yang berjudul "Metodologi penelitian Hadits Nabi" menguraikan ada beberapa langkah yang harus ditempuh dalam melakukan suatu kritikan terhadap sanad suatu hadits, $[1]$ yaitu sebagai berikut :

a. Melakukan I'tibar

Kata al-I'tibar (الاعتبار) adalah masdhar dari kata اعتبر yang menurut bahasa berarti peninjauan terhadap berbagai hal dengan maksud untuk dapat diketahui sesuatunya yang sejenis. 2$]$

Sedangkan menurut istilah ilmu hadits, I'tibar adalah menyertakan sanad-sanad yang lain untuk suatu hadits tertentu yang hadits itu pada bagian sanadnya tampak hanya terdapat seorang periwayat saja; dan dengan menyertakan sanadsanad yang lain tersebut akan dapat diketahui apakah ada periwayat yang lain ataukah tidak ada untuk bagian sanad dari sanad hadits yang dimaksud.[3]

Kegunaan I'tibar adalah untuk mengetahui keadaan sanad hadits seluruhnya dilihat dari ada atau tidak adanya pendukung berupa periwayat yang berstatus muttabī atau syāhid.[4] Dengan 
adanya I'tibarini maka akan diketahui apakah hadits yang diteliti itu memiliki muttabī dan syāhid ataukah tidak.

b. Pembuatan Skema Sanad

Untuk mempermudah proses kegiatan I'tibaritu diperlukan adanya pembuatan skema untuk seluruh sanad untuk hadits yang akan diteliti. Ada 3 hal yang harus diperhatikan :

1) Jalur seluruh sanad,

2) Nama-nama periwayat untuk seluruh sanad

3) Metode periwayatan yang digunakan oleh masing-masing periwayat ${ }^{3}$.

c. Meneliti Pribadi Periwayat dan Metode Periwayatannya

Untuk meneliti hadits diperlukan sebuah acuan yaitu acuan yang akan digunakan untuk meneliti kesahihan hadits bila hadits yang diteliti bukanlah hadits yang mutawatir.

Abū 'Amr Usmān bin Abdirrahman bin asSalah asy-Syahrazuri yang biasa disebut Ibnus Salah (w. 577 H/ 1245 M), beliau merumuskan sebagai berikut :

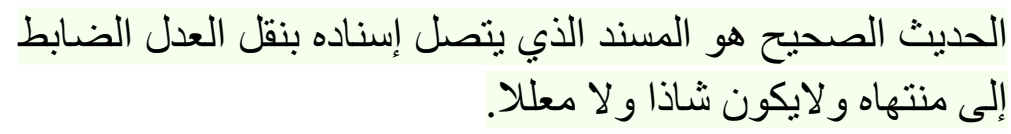

3 Yaqub, Ali Mustafa, Kritik Hadits, (Jakarta: Pustaka Firdaus, 2008), hlm. 87. 
Hadits Shahih ialah hadits yang bersambung sanadnya (sampai kepada Nabi SAW), diriwayatkan oleh (periwayat) yang adil dan dhābit sampai akhir sanad ( di dalam hadits itu) tidak terdapat kejanggalan (Syudzudz) dan cacat ('illat).[5]

Jadi unsur-unsur hadits dikatakan shahih apabīla sesuai dengan kaidah-kaidah sebagai berikut : a. Sanad hadits yang bersangkutan harus bersambung mulai darimukharrijnya sampai kepada Nabi Muhammad SAW.

b. Seluruh periwayat dalam hadits itu harus bersifat adil dan dhābit.

c. Hadits itu, jadi sanad dan matannya harus terhindar dari kejanggalan (Syudzudz) dan cacat ('illat).

Dari ketiga kaidah di atas ada yang berhubungan dengan sanad dan ada pula yang berhubungan dengan matan hadits.

a. Yang berhubungan dengan sanad :

1) Sanad bersambung

2) Seluruh periwayat dalam sanad bersifat adil

3) Seluruh periwayat dalam sanad bersifat dhābit

4) Sanad hadits itu terhindar dari kejanggalan (syudzudz)

5) Sanad hadits itu terhindar dari cacat ('illat)[6]

b. Yang berhubungan dengan matan :

1) Terhindar dari kejanggalan (syudzudz) 
2) Terhindar dari cacat ('illat)

Berikut ini akan dijelaskan kaidah-kaidah kesahihan hadits yang berhubungan dengan sanad, yaitu sebagai berikut ${ }^{4}$ :

1) Sanad Bersambung

Sanad bersambung adalah tiap-tiap periwayat dalam sanad hadits menerima riwayat hadits dari periwayat terdekat sebelumnya; keadaan itu berlangsung demikian sampai akhir sanad hadits itu. [7]

Dalam kitab Ilmu Hadisada 8 macam periwayatan, yaitu :as-sama', al-qira'ah, al-ijazah, al-munawalah, al-mukatabah, al-i'lam, alwassiyahdan al-wijadah. ke delapan metode periwayatan tersebut memiliki perbedaan dalam tingkat akurasinya. kegiatan menerima riwayat hadits dalam ilmu hadits dinamakan dengan tahammul al-hadits, sedangkan kegiatan menyampaikan riwayat hadits disebut ada'u alhadits

2) Seluruh periwayat dalam sanad bersifat adil

Dari berbagai perbedaan pendapat itu dapat dihimpunkan kriteria sifat adil yaitu :

a) Beragama Islam

b) Mukallaf

c) Melaksanakan ketentuan agama

4 Ibid.,hlm. 87. 
d) Memelihara murū'ah.[18]

Berdasarkan kriteria sifat adilyang telah dikemukakan di atas, maka hadits yang diriwayatkan oleh orang-orang yang suka berdusta, suka berbuat munkar, atau sejenisnya tidak dapat diterima sebagai hujjah. Bila riwayatnya juga diterima sebagai hadits, maka kedudukannya adalah sebagai hadits dha'if (lemah) dan oleh sebagian ulama dinyatakan sebagai hadits maudhu' (palsu).[23] Untuk mengetahui adil atau tidaknya seorang periwayat hadits haruslah diteliti terlebih dahulu kualitas pribadinya dengan kesaksian para ulama, dalam hal ini adalah ulama ahli kritik periwayat.

3) Seluruh Periwayat Dalam Sanad bersifat dhābit

Arti harfiah dhābit ada beberapa macam

a) Periwayat yang bersifat dhābit ialah :

(1) Periwayat yang hafal dengan sempurna hadits yang diterimanya, dan

(2) Mampu menyampaikan dengan baik hadits yang dihafalnya itu kepada orang lain.

b) Periwayat yang bersifat dhābit ialah periwayat yang selain disebutkan dalam butir pertama di atas juga dia mampu memahami dengan baik hadits yang dihafalnya itu.[27]

Rumusan pertama merupakan rumusan kriteria sifat dhābit umum, sedangkan yang 
kedua disebut sebagai tam dhābit atau dhābit plus.

4) Terhindar dari Syudzudz (kejanggalan)

Menurut bahasa kata syadz, dapat berarti; jarang, yang menyendiri, yang asing, yang menyalahi aturan dan yang menyalahi orang banyak. Mahmud Thahan dalam kitab "Tafsir Mushthalah al-Hadits" menyebutkan :

$$
\text { الثذوذ هو مخالفة الثقة لمن هو أوثق منه }
$$

Syudzudz ialah berbeda dengan hadits yang tsiqātatau berbeda dengan yang lebih tsiqāt daripadanya.[30]

5) Terhindar dari 'Illat (cacat)

'Illatialah sebab yang tersembunyi yang merusak kualitas hadits. Keberadaannya menyebabkan hadits yang pada lahirnya tampak berkualitas shahih menjadi tidak shahih.[33]

Adapun cara meneliti 'illat suatu hadits adalah dengan cara membanding-bandingkan semua sanad yang ada untuk matn yang isinya semakna.

Dalam kegiatan kritik sanad, beberapa massalah sering di hadapi oleh peneliti hadits, misalnya :

a) Adanya periwayat yang tidak disepakati kualitasnya oleh para kritikus hadits 
b) Adanya sanad yang mengandung lambanglambang 'anna, 'an, dan yang semacamnya.

c) Adanya matan hadits yang memiliki banyak sanad, tetapi semuanya lemah (dha'if). ${ }^{5}$

\section{Metode kritik matan}

\section{Teori Kritik Matan}

Dalam Ilmu Dirayah Hadis, kritik matan bisa dilakukan dengan dua cara; Pertama, kritik terhadap redaksi matan hadis, dan kedua, kritik terhadap makna matan hadis.Mengingat bahwa metode penyandaran Hadis yang dilakukan secara maknawi lebih banyak dipakai dalam periwayatan Hadis, maka kritik matan menjadi sangat penting. Metode ini sarat dengan subjektifitas perawi, karena mereka hanya mengambil inti dari apa yang didengar atau dilihat dari Nabi saw., kemudian menyampaikannya menurut kepekaan intelektual masing-masing.

a. Kritik Matan Pra Kodifikasi

Dari berbagai teknik dalam kritik matan hadis periode ini secara umum dapat dikategorikan memakai metode perbandingan (comparative). Dan atau rujuk silang (cross reference). Diantaa tehniktehnkik perbandingan yang tercatat pernah dipraktikkan adalah dengan teknik sebagai berikut:

${ }^{5}$ M.Syuhudi Ismail, Op.cit., hlm. 94 
1) Membandingkan matan hadits dengan ayat alQuran yang berkaitan.

Teknik ini kerap kali dilakukan oleh sejumlah sahabat nabi.Umar bin Khattab misalnya, ia pernah mempertanyakan dan kemudian menolak hadis yang diriwayatkan oleh fatimah bin Qais yang menyatakan bahwa wanita yang dicerai tidak berhak menerima uang nafkah (dari mantan suaminya). Menurut umar (matan) hadis tersebut, bila dibandingkan tidak sejalan dengan bunyi ayat al-Qur-an. Demikian juga Aisyah, dalam beerapa kasus ia pernah mengkritik sejumlah (matan) hadis yang disampaikan (diriwayatkan) oleh sahabat lainyya yang menurut pemahamannya tidak sejalan dengan kadnungan ayat al-Quran. Sebagai contoh beliau mengkritik hadis yang disampaikan oleh Abu Hurairah, Ibnu Abbas dan Ibnu Umar yang menyatakan bahwa orang yang meninggal dunia akan disiksa karena ratapan tangis keluarganya. Menurut Aisyah hal tersebut tidak sejalan dengan al-Quran.

2) Membandingkan (matan-matan) hadis dalam dokumen tertulis dengan hadis-hadis yang disampaikan dari hafalan.

Dalam teknik ini apabila ada perbedaan antara versi tulisan dengan versi lisan para 
ulama biasanya lebih memilih versi tulisan daripada versi lisan, karena dianggap lebih kuat (ahfaz). Imam bukhari misalnya, beliau pernah melakukan tekhnik ini pada saat menghdapi matan hadis tentang mengangkat tangan ketika akan ruku dalam shalat yang diriwayatka oleh sufyan melalui ibnu masy'ud setelah membandingkannya, Bukhari memutuskan untuk memilih hadis yang diriwayatkan oleh yahya bin adam yang telah mengeceknya dari kitab Abdullah bin Idris (dalam versi tulisan), dan pada matan tersebut tidak memuat redaksi yang mengundang perselisihan.

3) Perbandingan antara pernyataan dari seorang periwayat yang disampaikan pada waktu yang berlainan

Teknik perbandingan ini pernah digunakan oleh Aisyah salah seorang istri nabi. Aisyah pernah meminta keponakannya, yaitu Urwah bin Zubair untuk menanyakan sebuah hadis, yaitu tentang ilmu dan dihilangkannya ilmu dari dunia, kepada Abdullah bin Amr bin al-As yang tengah menunaikan ibadah haji. Abdullah pun menyampaikan hadis yang ditanyak itu. Karena Aisyah merasa tidak puas, tahun berikutnya, ia meminta Urwah kembali menemui Abdullah yang naik haji lagi dan 
menanyakan hadis yang telah ditanyakannya settahun yang lalu. Ternyata lafal hadis yang disampaikan oleh Abdullah sama persisi dengan lafal yang disampaikannya setahun yang lalu

4) Membandingkan hadis-hadis dari beberapa murid yang mereka terima dari satu guru.

Teknik ini misalnya dipraktikkan oleh (yahya) Ibnu Ma'in salah seorang ulama kritikus hadis terkemuka. Ia pernah membandingkan karya Hammad bin Salamah seorang terkenal dari Basrah, dengan cara menemui dan mencermati tulisan delapan belas orang murid Hammad. Dari hasil perbandingan tersebut ternyata Ibnu Ma'in menemukan kesalahankesalahan baik yang dilakukan oleh Hammad maupun murid-muridnya.

5) Melakukan rujuk silang antara satu periwayat dengan periwayat lainnya

Teknik ini pernah dilakukan oleh Marwan bin Hakam. Peristiwanya bermula saat Marwan menerima hadis yang disampaikan oleh Abd arRahman bin al-Mugirah bin Hisyam bin alMugirah yang bersumber dari Aisyah dan Ummu Salamah yang menyatakan bahwa Rasulullah SAW.ketika waktu fajar (salat subuh) beliau dalam keadaan berhadas besar (karena pada malam harinya bersenggama 
dengan istri beliau). Kemudian beliau mandi dan tetap berpuasa (pada hari itu). Mendengar hadis tersebut, marwan segera menyuruh Abd ar-Rahman menemui Abu Hurairah, karena Abu Hurairah pernah meriwayatkan hadis yang menyatakan bahwa apabila seseorang pada waktu subuh dalam keadaan hadas besar karena pada malam harinya bersenggama dengan istrinya, maka nabi menyuruh orang tersebut membuka puasanya. 'Abd ar-Rahman menemui Abu Hurairah di Zulhulaifah, dan menyampaikan kepadanya hadis yang diriwayatkan melalui Aisyah dan Ummu Salah. Pada saat itu Abu Hurairah menjelaskan bahwa ia menerima hadis tersebut tidak langsung dari nabi, melainkan dari al-Fadl bin Abbas, sehingga menurut Abu Hurairah Fadl lah yang lebih mengetahui hadis tersebut.

Memperhatikan tehnik-tehnik yang dilakukan dalam kritik matan hadis pra kodifikasi diatas, tekhnik yang pertama yaitu membandingkan matan hadis dengan al-Quran masih mungkin dilakukan untuk kritik matan pasca kodifikasi. Sedangkan tehnik-tehnik lainnya tidak mungkin diaplikasikan terhadap kritik matan pasca kodifikasi, jika tehnik perbandingan itu dilakukan dalam pengertian 
menemui langsung para periwayat. Namun, secara substansial, tehnik-tehnik kritik matan butir kedua sampai kelima dapat diaplikasikan untuk kritik matan pasca kodifikasi dengan cara membandingkan matan-matan hadis melalui penelusuran dan analisis keseluruhan para periwayat dan sanad-sanadnya.

Jadi dapat dinyatakan bahwa metode kritik model pertama ini lebih merupakan pengalaman sejarah, karena hadis-hadis nabi sekarang ini telah dikodifikasikan. Namun demikian, sebagian metodenya, masih ada yang relevan untuk diterapkan terhadap model kedua dengan adanya modifikasi.

b. Kritik Matan Pasca Kodifikasi

Seperti halnya kritik matan hadis pra kodifikasi, untuk kritik matan pasca kodifikasi pun metode perbandingan tetap masih dominan dan relevan, hanya saja teknik-tekniknya perlu disesuaikan sebagaimana telah disinggung sebelumnya. Secara rinci, dapat diuraikan bahwa teknik kritik matan pada fase ini, termasuk zaman sekarang, dapat dilakukan antara lain dengan teknik sebagai berikut:

1) Membandingkan matan-matan hadis dengan ayat al-Qur'an yang terkait atau memiliki kedekatan susunan redaksi. 
Teknik ini sesungguhnya tidak lagi sekedar kritik perbandingan teks, tetapi perlu melibatkan aspek pemahaman atau pemaknaan teks. Membandingkan teks atau matan-matan hadis dengan ayat-ayat al-Qur'an dari susunan redaksi adalah kurang proposional, karena redaksi atau lafal-lafal al-Qur'an diriwayatkan secara mutawatir, sedangkan matan-matan hadis hampir seluruhnya diriwayatkan menurut maknanya saja (riwayah bi al-ma'na). Namun demikian, perbandingan teks ini bukanlah hal yang mustahil dilakuan, dan analisis perbandingan matan-matan hadis dengan alQur'an tetap membantu proses kritik, misalnya ketika terjadi perbandingan matan-matan hadis yang semakna dengan redaksi yang berbeda, sementara terdapat ayat alQur'an yang memiliki kemiripan (susunan redaksinya). Dalam konteks ini jelaslah bahwa keakuratan dalam penujukan ayat yang menjadi pembandingnya merupakan prasyarat untuk dapat melakukan kritik matan hadis melalui ayat al-Qur'an.

2) Membandingkan antara matan-matan hadis.

Agar dapat melakukan kritik matan hadis dengan teknik ini, hendaknya didahului dengan langkah pertama yaitu menghimpun matan- 
matan hadis. Untuk itulah penelusuran hadishadis (secara lengkap sanad dan matannya) kepada sumber-sumber aslinya yang dikenal dengan istilah takhrij al-hadis, dalam tahap ini sangatlah diperlukan. Matan-matan hadis hendaknya yang memiliki kesamaan makna, dan lebih bagus lagi yang susunan redaksi atau lafalnya satu sama lain memiliki kemiripan. Ini penting karena dimungkinkan bahwa hadishadis itu pada mulanya bersumber dari orang yang sama, kemudian mengalamai perbedaan redaksi karena diriwayatkan oleh para periwayat berikutnya secara makna. Namun, jika hadisnya hanya satu (teks atau naskah tunggal), tetap bisa diajukan untuk dilakukan kritik matan/teks. Dari segi kualitas, idealnya matan-matan hadis yang hendak diteliti, sanadnya pun telah diteliti dan dinyatakan sahih. Dengan demikian kegiatan kritik matan merupakan kegiatan lanjutan dari kegiatan kritik sanad. Di samping itu, dalam keadaan tertentu terkadang diperlukan skema sanad dari semua hadis yang dihimpun (melakukan i'tibar as-sanad) untuk mengetahui kemungkinan ada tidaknya persambugan dan pertemuan para periwayat dalam sanad-sanad tersebut dan keterkaitannya dengan 
perbandingan susunan redaksi matan di antara matan-matan yang akan dikritisi.

Cara menghimpun matan-matan hadis untuk kepentingan kritik matan ini, ialah dengan melihat kitab-kitab kumpulan hadis yang menggunakan sistematika perbab atau pertema, seperti kitab-kitab hadis yang tergolong kategori sunan. Selain itu, dapat pula mengambilnya dari kitab-kitab kumpulan hadis tematik seperti kitab Riyad as-Salihin karya Imam Nawawi, dan kitab Bulug al-Maram karya Ibnu Hajar al-Asqalani. Hanya saja pada kitabkitab tematik, hadis-hadisnya tidak disertai sanad sehingga ketika diperlukan analisis sanad untuk menelusuri dan membandingkan matan-matannya harus merujuk kepada kitabkitab aslinya. Cara lainnya, dapat ditempuh dengan melakukan penelusuran berdasarkan lafal yang sama atau lafal-lafal yang berbeda namun memiliki kesamaan atau kemiripan makna. Untuk ini dapat menggunakan bantuan al-Mu'jam al-Mufahras li Alfaz al-Hadis anNabawi. Dapat pula menelusuri hadis-hadis tematik dengan bantuan Miftah Kunuz asSunnah.

Setelah matan-matan hadis terkumpul, langkah berikutnya adalah menganalisis atau 
mengkritiknya secara cermat dengan cara membandingkan matan-matan hadis satu sama lain. Perbandingan matan-matan hadis terutama menyangkut persamaan dan perbedaan antar matan dalam pemakaian lafallafalnya dan susunan redaksinya. Hal yang tidak kalah pentingnya dalam perbandingan antar matan itu adalah kemungkinan adanya perbedaan dalam hal tambahan redaksi atau lafal, yakni adanya idraj atau ziyadah. Hal tersebut bisa saja terjadi karena adanya tambahan atau kekurangan lafal atau redaksi baik karena adanya unsur kesengajaan (dengan tujuan yang semula positif), ataupun tidak, atau karena kekeliruan dan kelalaian periwayat yang sifatnya manusiawi.

Secara teknis, metode kritik matan hadis dengan membandingkan antara matan tertentu dengan matan-matan lainnya dapat dilakukan dengan beberapa cara, misalnya dengan melakukan perbandingan matan-matan hadis yang redaksinya ada perbedaan. Matanmatan hadis tersebut bisa saja masih dalam satu kitab yang disusun oleh satu penyusun/penghimpun (mukharij), ataupun pada kitab-kitab hadis yang berbeda, namun semuanya bersumber atau bertemu pada satu 
periwayat yang sama. Dari perbandingan itu biasanya ada saja perbedaan redaksi, namun perbedaan itu dapat ditoleransi sepanjang kandungannya sama.

Dari perbandingan itu biasanya ada saja perbedaan redaksi, namun perbedaan itu dapat ditoleransi sepanjang kandungannya sama. Namun, perbedaan redaksi menjadi penting dikritisi ketika ternyata di antara matan-matan hadis ada yang memuat kata atau kalimat tertentu sebagai tambahan ataupun kekurangan, sementara kata atau kalimat tersebut memuat informasi yang penting karena dapat menyamakan atau membedakan dengan matan-matan hadis lainnya. Bahkan persoalan sama tidaknya redaksi, bukan sekedar makna yang dikandungnya menjadi sesuatu yang signifikan misalnya matan atau redaksi hadis yang dipakai sebagai bacaan ibaadah, seperti bacaan-bacaan dalam salat, haji dan sebagainya. Untuk keperluan kajian metode tematik hadis pun, kritik matan ini sangat membantu. Dalam konteks ini, pengkaji matan-matan secara tematik, tidak akan tergesa-gesa menoleransi perbedaan dan menganggapnya bahwa perbedaan tersebut saling melengkapi atau menguatkan (ikhtilaf at- 
takamul aw at-tanasuk), namun akan terlebih dahulu menyeleksinya. Sayang, penulis baru melontarkan gagasan dan belum dapat mengemukakan contoh aplikasi kongkritnya.

3) Teknik lainnya yang dapat dilakukan ialah dengan cara membandingkan matan-matan hadis yang termuat dalam kitab-kitab hadis berdasarkan adanya perbedaan penulisan atau cetakan. Tentu saja hal ini dapat dilakukan, karena diawali dari membandingkan matan-matan hadis yang ternyata ada perbedaan.

4) Untuk ini penulis memberikan contoh tentang perbedaan redaksi ucapan salam dalam matanmatan hadis pada saat memalingkan wajah atau muka ke kanan dan ke kiri sebagai penutup dalam salat. Dalam berbagai naskah cetakan kitab hadis yang beredar di masyarakat terdapat perbedaan tentang keberadaan lafal "wa baraka>tuh" dalam ucapan salam. Dalam naskah cetakan Sunan Abi Da>wud misalnya, menurut hasil penelitian Muhamad bin asySyaikh 'Ali< bin $\mathrm{A}<$ dam al-As $\backslash \mathrm{yu}>\mathrm{bi}<$, terdapat tiga macam naskah edisi cetakan yang satu sama lain masing-masing ada perbedaan. Pada naskah pertama, tidak terdapat lafal "wa baraka>tuh" ketika memalingkan wajah ke kiri, 
sementara pada cetakan lainnya lafal tersebut disebutkan semuanya baik ketika memalingkan wajah ke kanan maupun ke kiri. Kedua, pada naskah cetakan India yang terdapat di perpustakaan al-Mahmudiyyah di Madinah juz I halaman 138 ucapan asalamu'alaikum wa rahmatullaahi wa barakatuh diucapkan ketika memalingkan wajah ke kanan maupun ke kiri. Ketiga, Edisi naskah cetakan lainnya adalah yang terhimpun dalam al-Kutub atTis'ah (sembilan kitab hadis standar) yang dijadikan rujukaan oleh kitab indek hadis alMu'jam al-Mufahras li Alfaz al-Hadis an-Nabawi. Serta edisi naskah cetakan yang dikoreksi oleh 'Izzat 'Ubaid Da'as halaman 607. Edisi ini memuat dua macam naskah sebelumnya secara lengkap. Dari semua edisi naskah cetakan Sunan Abi Dawud tersebut, menurut penelitian al-Asyubi yang paling kuat adalah redaksi salam yang memuat lafal wa barakatuh ketika memalingkan wajah ke kanan dan ke kiri6.

Teknik-teknik perbandingan atau yang lainnya untuk melakukan kritik matan, dapat terus dikembangkan. Dan hal ini bisa dilakukan dengan

6 Kamil Sukron, Op. cit., hlm. 23. 
terus melakukan latihan atau praktik, terutama sekali lagi untuk hadis-hadis yang setopik.

c. Langkah-Langkah Kegiatan Dalam Kritik Matan Hadits

Syuhudi Isma'il mengungkapkan langkahlangkah dalam kegiatan penelitian matan hadits adalah :

1) Meneliti Matan dengan Melihat Kualitas Sanadnya

Dalam urutan kegiatan penelitian, ulama hadits mendahulukan penelitian sanad atas penelitian matan. Setiap matan harus mempunyai sanad, tanpa adanya sanad maka suatu matan tidak dapat dinyatakan sebagai berasal dari Rasulullah SAW.

Kualitas sanad dan matan suatu hadits cukup bervariasi, ada yang sanadnya shahih tetapi matannya dha'if, atau sebalikknya sanadnya dha'if tetapi matannya shahih, begitu pula ada yang sanad dan matannya berkualitas sama yakni sama-sama shahih atau sama-sama dha'if.

Menurut ulama hadits suatu hadits dikatakan berkualitas shahih (dalam hal ini shahih li zatih) apabīla sanad dan matannya sama-sama berkualitas shahih. Unsur-unsur 
yang harus dipenuhi oleh suatu matan yang berkualitas shahih adalah sebagai berikut :

a) Terhindar dari syudzudz (kejanggalan), dan

b) Terhindar dari 'Illat (cacat).

Menurut al-Khātib al-Bagdādi (w. 463 $\mathrm{H} / 1072 \mathrm{M})$, suatu matan hadits barulah dapat dinyatakan sebagai maqbul (diterima) apabīla:

(1) Tidak bertentangan dengan akal yang sehat

(2) Tidak bertentangan dengan hukum AlQur'an yang telah muhkam (yang dimaksud dengan istilah muhkam dalam hal ini ialah ketentuan hukum yang telah tetap; ulama ada yang memasukkan ayat yang muhkam ke dalam salah satu pengertian qath'iyyah dalālah)

(3) Tidak bertentangan dengan hadits mutawatir

(4) Tidak bertentangan dengan amalan yang telah menjadi kesepakatan ulama masa lalu (ulama salaf)

(5) Tidak bertentangan dengan dalil yang telah pasti.

(6) Tidak bertentangan dengan hadits ahadyang kualitas kesahihannya lebih kuat. ${ }^{7}$

7 Sumbulah, Umi. Kritik Hadis Pendekatan Historis Metodologis, UINMalangPress.Jln.Gajayana 50 Malang, 2008. 
Menurut jumhur ulama hadits tanda-tanda matan hadits yang palsu itu adalah :

(1) Susunan bahasanya rancu. Rasulullah SAW yang sangat fasih dalam berbahasa Arab dan memiliki gaya bahasa yang khas mustahil menyabdakan pernyataan yang rancu tersebut.

(2) Kandungan pernyataannya bertentangan dengan akal yang sehat dan sangat sulit diinterprestasikan secara rasional. Contohnya :

$$
\text { و الباذنجان شفاء من كل داء }
$$

(3) Kandungan pernyataanya bertentangan dengan tujuan pokok ajaran Islam, misalnya berisi ajakan untuk berbuat maksiat.

(4) Kandungan pernyataanya bertentangan dengan sunnatullah (hukum alam)

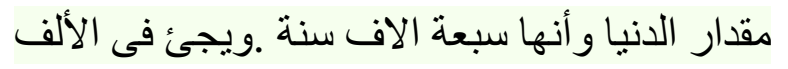

$$
\text { السابعة }
$$

(5) Kandungan pernyataanya bertentangan dengan fakta sejarah

(6) Kandungan pernyataanya bertentangan dengan petunjuk al-Qur'an ataupun hadits mutawatir yang telah mengandung petunjuk secara pasti.

$$
\text { ا خاتم النبين لا نبي بعدي إلا أن بشاء الله }
$$


(7) Kandungan pernyataanya berada di luar jalur kewajaran diukur dari petunjuk umum ajaran Islam; misalnya amalan yang tidak seberapa tetapi diiming-iming dengan balasan pahala yang sangat luar biasa. [56]

(8) Matan hadits tidak syadz dan tidak berillat.

Kemudian apabīla suatu hadits memenuhi persyaratan di muka, maka bisa dikategorikan sebagai hadits yang shahih al matan. Setelah suatu hadits melewati 2 pos sensor yaitu sensor aspek sanad dan sensor aspek matan, maka nilai hadits tersebut tidak akan lepas dari 4 kemungkinan :

(a) Sanad dan matan hadits bernilai shahih, sehingga hadits tersebut masuk dalam kelompok hadits shahih.

(b) Sanad dan matan hadits tidak shahih, sehingga hadits tersebut masuk dalam kelompok hadits ghair ash-shahih.

(c) Matan haditsnya shahih sementara sanadnya tidak shahih, sehingga hadits tersebut masuk dalam kelompok hadits ghair ash-shahih.

(d) Sananya shahih, sedangkan matannya tidak shahih, versi ini juga masuk dalam kelompok hadits ghair ash-shahih. 
Salahud-Din al-Adlabi menyimpulkan bahwa tolak ukur untuk penelitian matan ada 4 macam, yakni :

(a) Tidak bertentangan dengan petunjuk AlQur'an

(b) Tidak bertentangan dengan hadits yang lebih kuat

(c) Tidak bertentangan dengan akal yang sehat, indera, dan sejarah

(d) Susunan pernyataannya menunjukkan ciriciri sabda keNabian.

Penelitian matan itu tidak mudah dikarenakan ada beberapa faktor yaitu sebagai berikut :

(a) Adanya periwayatan secara makna

(b) Acuan yang digunakan sebagai pendekatan tidak satu macam saja

(c) Latar belakang timbulnya petunjuk hadits tidak selalu mudah dapat diketahui

(d) Adanya kandungan petunjuk hadits yang berkaitan dengan hal-hal yang berdimensi "supra rasional", dan

(e) Masih langkanya kitab-kitab yang membahas secara khusus penelitian matan hadits. ${ }^{8}$

sIbid., hlm. 35. 
Oleh karena penelitian matan hadits tidaklah mudah, maka ada beberapa syarat yang harus dipenuhi oleh seorang yang akan meneliti matan hadits tersebut, yaitu :

(a) Memiliki keahlian dibidang hadits

(b) Memiliki pengetahuan yang luas dan mendalam tentang ajaran Islam

(c) Telah melakukan kegiatan muthala'ah yang cukup

(d) Memiliki akal yang cerdas sehingga mampu memahami pengetahuan secara benar

(e) Memiliki tradisi keilmuan yang tinggi.[60]

Adapun masalah yang sering di hadapi dalam kegiatan kritik matan adalah masalah metodologis dalam penerapan tolak ukur kaidah kritik matan terhadap matan yang sedang diteliti. Hal itu disebabkan oleh butir-butir tolak ukur yang memiliki banyak segi yang dilihat. Sering pula peneliti menghadapi matan-matan hadits yang ditelitinya tampak bertentangan. Dalam hal ini perlu kecermatan dan keahlian dalam menggunakan metode-metode kritik matan hadits.

Dengan demikian, maka jelaslah bahwa pengetahuan-pengetahuan tentang asbabu al wurud hadits, mukhtalaf al hadits, sosiologi, antropologi, dan lain-lain perlu dimiliki oleh peneliti matan hadits. 
2. Meneliti Susunan, Lafal Matan yang Semakna

Salah satu penyebab terjadinya perbedaan lafal matan hadits yang semakna adalah karena dalam periwayatan hadits telah terjadi periwayatan secara makna. Misalnya hadits tentang perdamaian :

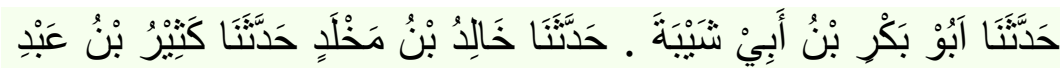

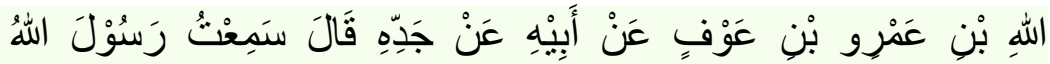

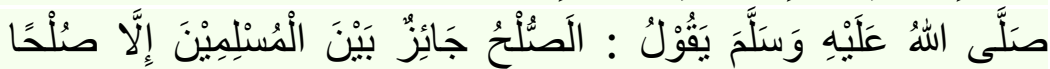

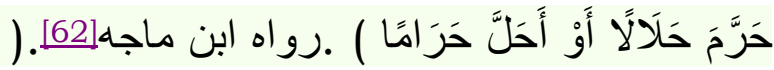

$$
\begin{aligned}
& \text { وفى رواية الاخرى: }
\end{aligned}
$$

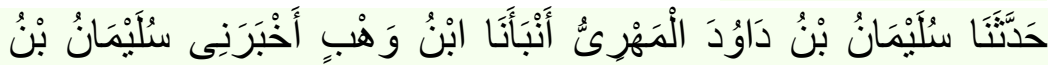

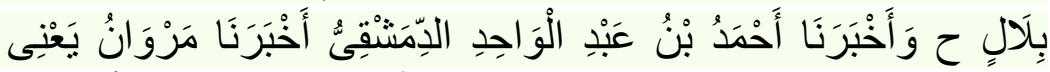

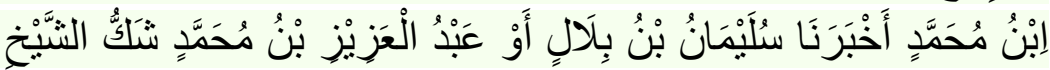

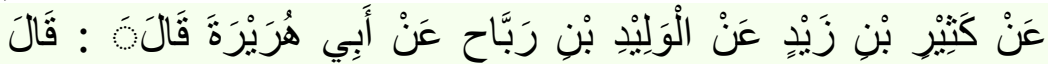

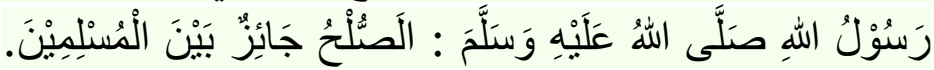

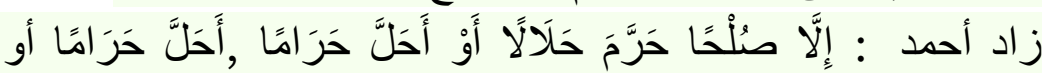
حَرَّمَ حَلَالًا.

زاد سليمان ين داود : وقال حُّلان رسول الله صلى الله عليه وسلم :

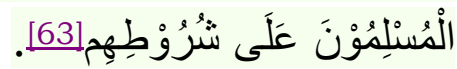

Artinya :

"Telah memberitahukan kepada kami Abū Bakar bin Abī Syaibah, telah memberitahukan kepada kami Khalid bin Makhlad, telah memberitahukan kepada kami Katsir bin Abdullah bin Amru bin Auf dari ayahnya dari kakeknya katanya: Aku telah mendengar Rasulullah SAW bersabda: "Perdamaian (membuat kesepakatan) itu diperbolehkan di antara orang-orang muslim, kecuali perdamaian (kesepakatan) untuk mengharamkan sesuatu yang halal atau menghalalkan sesuatu yang haram. (HR. Ibnu Majjah). 
Dan pada riwayat yang lain:

"Telah memberitahukan kepada kami Sulaiman bin Daud Al-Mahri, katanya: telah memberikan khabar kepada kami Ibnu wahab, katanya: telah memberitahukan kepadaku Sulaiman bin Bilal dan telah memberitahukan kepada kami Ahmad bin Abdul wahid Ad-Dimasyqi katanya: telah memberitahukan kepada kami Marwan yaitu Ibnu Muhammad katanya: telah memberikan berita kepada kami Sulaiman bin Bilal atau Abdul 'Aziz bin Muhammad Syakku Syaikh dari Katsir bin Zaid dari Al-Walid bin Rabbah dari Abū Hurairah r.a, katanya: Rasulullah SAW telah bersabda: "Perdamaian (membuat kesepakatan) itu diperbolehkan di antara orang-orang muslim. Ahmad menambahkan: kecuali perdamaian (kesepakatan) untuk mengharamkan sesuatu yang halal atau menghalalkan sesuatu yang haram atau untuk menghalalkan yang haram atau mengharamkan yang halal. Sulaiman bin Daud menambahkan: Rasulullah SAW bersabda: Orangorang muslim (dalam perdamaian tersebut) bergantung pada syarat-syarat mereka. ${ }^{9}$

Akibat dari perbedaan lafal itu adalah :

a) Metode muqarranah (perbandingan)

Dengan adanya perbedaan lafal pada matan yang semakna itu, maka metode muqarranah ini sangat penting untuk dilakukan, maka akan dapat diketahui apakah terjadinya perbedaan lafal pada matan tersebut masih dapat ditoleransi atau tidak. Metode ini tidak hanya dimaksudkan untuk mengkonformasi atas hasil penelitian yang telah ada saja melainkan sebagai upaya untuk lebih

9http://sukmanila.multiply.com/journal/item/22 
mencermati susunan matan yang lebih dapat dipertanggungjawabkan keorisinilannya berasal dari Rasulullah SAW.

b) Ziyadah, idraj, dan lain-lain

Ziyadah artinya tambahan. Ziyadah menurut ilmu hadits artinya tambahan lafal ataupun kalīmat (pernyataan) yang terdapat pada matan, tambahan itu dikemukakan oleh periwayat tertentu, sedang periwayat tertentu lainnya tidak mengemukakannya.

Menurut ibnu Shalah, ziyadah ini ada 3 macam :

(1) Ziyadah yang berasal dari periwayat yang tsiqāh yang isinya bertentangan dengan yang dikemukakan oleh banyak periwayat yang bersifat tsiqāh juga; ziyadah tersebut ditolak. Ziyadah seperti ini termasuk syadz.

(2) Ziyadah yang berasal dari periwayat yang tsiqāh yang isinya tidak bertentangan dengan yang dikemukakan oleh banyak periwayat yang bersifat tsiqāh juga; ziyadah tersebut diterima. Kata al-Khatib al-Bagdadi pendapat tersebut merupakan kesepakatan ulama.

(3) Ziyadah yang berasal dari periwayat yang tsiqāh berupa sebuah lafal yang mengandung arti tertentu, sedang periwayat lainnya yang 
bersifat tsiqāh tidak mengemukakannya. Ibnus salah tidak mengemukakan penjelasan tentang bagaimana kedudukan ziyadah model ketiga ini. 10

\section{Meneliti Kandungan Matan}

a. Membandingkan kandungan matan yang sejalan atau tidak bertentangan

Setelah susunan lafal matan hadits tersebut diteliti, maka langkah selanjutnya adalah meneliti kandungan matan. Untuk itu harus dikumpulkan hadits-hadits yang membahas tentang topik yang sama yang akan diteliti kualitas matannya, maka perlu dilakukan takhrijul hadits bil maudhu'. Jika ada matan lain yang bertopik sama, maka sanadnya harus diteliti terlebih dahulu, setelah itu apabīla sanadnya sudah dinyatakan memenuhi syarat, maka kegiatan muqarranah ini dilakukan.

Jika kandungan matan hadits yang diperbandingkan sama, maka dapat dikatakan penelitian telah berakhir. Tetapi dalam praktek kegiatan biasanya masih dilanjutkan dengan melihat syarah-syarah hadits tersebut. Jika kandungan matan yang diteliti sejalan juga dengan dalil-dalil yang lebih kuat, minimal tidak bertentangan, maka dapat dikatakan penelitian telah selesai.[65]

10Sumbulah, Umi, Op. Cit., hlm. 47. 
b. Membandingkan kandungan matan yang tidak sejalan atau tampak bertentangan.

Sesungguhnya tidak mungkin hadits Nabi bertentangan dengan hadits Nabi yang lain dan dengan Al-Qur'an, karena keduanya sama-sama datang dari Allah SWT. Namun pada kenyataanya ada sejumlah hadits Nabi yang tampak bertentangan atau tidak sejalan, jika demikian pasti ada sesuatu yang melatarbelakanginya. Dalam menyebut kandungan matan hadits yang tampak bertentangan itu, ulama tidak sependapat. Sebagian ulama menyebutnya dengan istilah mukhtaliful hadits, sebagian lagi menyebutnya mukhalafatul hadits, dan pada umumnya ulama menyebutnya dengan at-ta'arud. Ulama sependapat bahwa hadits-hadits yang tampaknya bertentangan satu sama lain tersebut harus diselesaikan sehingga hilanglah pertentangan itu.

Dalam hal ini asy-Syafi'i memberi gambaran bahwa mungkin saja matan hadits yang tampak bertentangan itu mengandung petunjuk :

(1) Matan yang satu bersifat global (mujmal) dan yang lain bersifat rinci (mufassar).

(2) Mungkin yang satu bersifat umum ('amm) dan yang lainnya bersifat khusus (khash). 
(3) Mungkin matan yang satu sebagai penghapus (an-nasikh) dan yang lain sebagai yang dihapus (al-mansukh), atau;

(4) Kedua-duanya menunjukkan kebolehan untuk diamalkan. ${ }^{11}$

Contoh Hadits yang Tampak bertentangan

Dalam hadits riwayat Muslim, ad Darimi dan Ahmad dinyatakan :

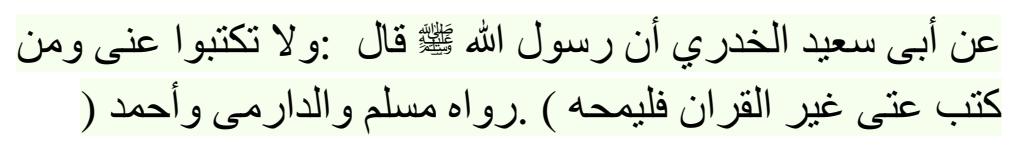

Artinya :

(hadits Riwayat) dari Abū Sa'id al-Khudri bahwa Rasulullah SAW telah bersabda: janganlah kamu tulis (apa yang berasal) dariku dan barangsiapa yang telah menulis dariku selain Al-Qur'an, maka hendaklah dia menghapusnya.[68]Hadits di atas tampak bertentangan dengan hadits riwayat alBukhari, Muslim dan Abū Daud yang berbunyi :

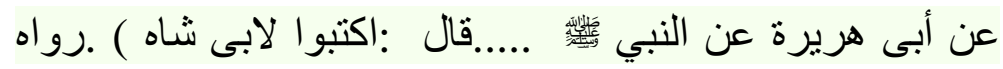

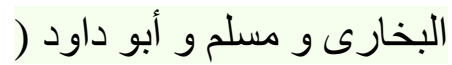

(hadits riwayat) dari Abū Hurairah, dari Nabi SAW.....beliau bersabda (kepada para sahabat): tuliskanlah (khutbah saya tadi) untuk Abū Syah (yang telah minta untuk dituliskan tersebut).669]

11Azami, Muhammad Musthafa, Metodologi Kritik Hadis, Terjemahan A.Yamin, (Jakarta: Pustaka Hidayah,1992), hlm. 


\section{Penutup}

Secara garis besar meliputi dua kegiatan atau tahapan yaitu meakukan metode kritik sanad dan melakukan metode kritik matan atau seleksi matan hadtis.

\section{DAFTAR PUSTAKA}

Azami, Muhammad Musthafa. Metodologi Kritik Hadis. Terj. A. Yamin. Jakarta: Pustaka Hidayah, 1992.

Ismail, M. Syuhudi. Kaedah Kesahihan Sanad Hadis: Telaah Kritis dan Tinjauan dengan Pendekatan Ilmu Sejarah. Jakarta: Bulan Bintang, 1988.

Kamil, Sukron, Naqd Al-Hadis, ter. Metode Kritik Sanad dan Matan Hadis, Pusat Penelitian Islam Al-Huda

Sumbulah, Umi.M.Ag., Kritik Hadis Pendekatan Historis Metodologis. UIN-Malang Press. Jln. Gajayana 50 Malang.2008

Yaqub, Ali Mustafa, Kritik Hadis, Jakarta : Pustaka Firdaus, 2008.

http://sukmanila.multiply.com/journal/item/22 